\title{
Parental Participation of Imam Hatip High-School Students in Children's Education: A Qualitative Study Based on School Administrators' Views*
}

\author{
İbrahim Așlamac1 ${ }^{1}$
}

\author{
Emrah Eker ${ }^{2}$
}

\begin{abstract}
The purpose of this research is to use school administrators' views to examine parental participation in the education process of students attending Imam Hatip High School. The research follows a qualitative research model. Performed comprehensively in Turkey during the spring semester of the 2015-16 academic year, the research study group consisted of a total of 25 school administrators from 24 different Imam Hatip High Schools in 12 provinces designated as Level 1 by the Turkish Statistics Institute. A semi-structured interview form developed by the research with the help of experts was used to collect data through face-to-face interviews conducted with school administrators. Adescriptive analysis of the results showed that IHHS school administrators found that although most of the students' parents did not to participate in the educational process, they still have very high expectations from these schools. Additionally, school administrators expressed a high number of negative characteristics while describing parent profiles, characterizing the majority of parents' cooperation and involvement in the educational process as weak. They stated that parents had different expectations from the school, and in this sense many of the parents considered their children's academic achievement to be more important than their gaining of religious values.
\end{abstract}

\section{Keywords}

Parents of Imam Hatip High School students • Family participation in the education process •

School-family relationship

\footnotetext{
* This is an extended abstract of the paper entitled "İmam-Hatip Lisesi Öğrenci Velilerinin Çocuklarının Eğitimine Katılım Durumları: Okul Yöneticilerinin Görüşlerine Dayalı Nitel Bir Araştırma” published in Talim: Journal of Education in Muslim Societies and Communities.

The preparation of this paper was supported in part by the Values Education Center under the Project "İmam-Hatip Okulları Araştırmaları Projesi." Some of the data are retrieved from the Project.

An earlier version was presented at "Geleceğin İnşasında İmam-Hatip Okulları Uluslararası Sempozyumu," a conference held at İnönü University, May 27-29, 2017.

Manuscript Received: May 30, 2017 / Revised: July 30, 2017 / Accepted: August 30, 2017 / OnlineFirst: December $20,2017$.

1 Correspondence to: İbrahim Aşlamacı (PhD), Faculty of Theology, İnönü University, Battalgazi, Malatya 44280 Turkey. Email: ibrahim.aslamaci@inonu.edu.tr

2 (PhD Candidate) Faculty of Theology, İstanbul University, Fatih, İstanbul 34660 Turkey. Email: emrah.eker@istanbul.edu.tr

To cite this article: Aşlamac1, İ., \& Eker, E. (2017). Parental participation of Imam Hatip High-School students in children's education: A qualitative study based on school administrators' views. Talim: Journal of Education in Muslim Societies and Communities, 1, 153-185. http://dx.doi.org/10.12738/talim.2017.2.0007
} 
Family and school are two of the more active social institutions effective in shaping a healthy personality and in imbuing individuals with the necessary skills to live in socio-cultural harmony with society. Families have the potential to make significant contributions to their children's academic success not only by establishing healthy communication with their children and providing them with an environment sensitive to learning but also through their cooperation with school administrators and teachers. For this reason, a healthy communication network between the family and school as well as a sufficient exchange of information about the child carries great importance in a student's academic success. Even more important is the significance of school-family cooperation in the child's school education, as is increasingly apparent with each passing day. However, despite various research on the different types and levels of parents' participation in the education process in the relevant national (i.e., Turkish) literature, no study directly related to parental participation by parents of students attending Imam Hatip High Schools (IHHSs) was encountered. Since no such study exists and since IHHS are comprise a major segment of secondary schools in the Turkish education system, examining this subject is considered worthy of investigation.

\section{Purpose of the Research}

The aim of this research is to investigate participation in the education process by parents of IHHS students based on school administrators' opinions. Using the opinions of school administrators, as they formed the study group of this research, responses to the following questions were sought:

1- According to IHHS school administrators, how are parents' profiles in terms of their participation in their children's education process?

2- Based on the statements of IHHS administrators, do students' parents actively cooperate with and provide both material and moral support to faculty and staff for the sake of their children's education?

3- According to IHHS school administrators, what are parents' expectations from the school?

\section{Method}

The research was designed following a qualitative, case-science approach. The study group was identified using the maximum diversity sampling technique, a purposeful sampling method. In order for the data to reflect the situation in all IHHSs in Turkey as faithful to reality as possible, the Turkish Statistics Institute's (TurkStat) classifications of Turkey's Regions were utilized to identify the provinces. As such, a total of 12 provinces designated as Level 1 by TurkStat were selected as the sample 
provinces for the research. Interviews were planned with those school administrators officiating in at least two IHHSs per province. In this way, the research study group was composed of 25 school administrators officiating in a total of 24 IHHSs located in 12 different provinces during the 2015-2016 school year.

A semi-structured interview form developed by the researchers was used to gather the data. In creating the interview form, the questions were first prepared and then trial interviews were performed. Following the pilot interviews, the interview form was brought to its final form after taking into account the opinions and suggestions received from field experts. Data were gathered by way of face-to-face interviews that were conducted with the school administrators and were analyzed using the descriptive analysis technique.

\section{Findings}

Based on data obtained in the research, IHHS school administrators were found to deal with family involvement more in terms of school-based parental participation duties, touching much less in their comments upon the roles of family participation outside of school.

Half of the IHHS school administrators interviewed found the parents to be uninvolved in terms of participation in the education-learning process, characterizing not only parents' cooperation with stakeholders but also their support in the education process as weak. Some of the participants tied parental lack of involvement to parents' over-reliance on these schools and to the notion held by parents that their responsibilities finish upon sending their children to these schools.

According to the participants, students' parents have different expectations from IHHSs. In this respect, the participants have revealed two types of parent profiles. The first and larger group expected IHSSs to help their children attain academic success. In contrast, parents expecting their children to gain religious values in particular form the minority. On the point of expectations, academic achievement is ranked first and gaining religious values second.

Regarding parent profiles, (i) five participants described parents as not having sufficient pedagogical knowledge or economical standing, (ii) six participants stated that parents were influenced and manipulated by their children regarding problems in student-school relations and tended to think their student was always in the right, (iii) five participants stated that due to the system, parental participation was integral to IHHS, (iv) four participants mentioned that the parents exhibited a very assertive attitude on sending their child to IHHSs, (v) two participants mentioned parents experiencing domestic problems, and (vi) one participant described a parent who 
expected over-the-top attention and service for their child for having sent his child to an IHHS. As such, school administrators have developed a higher number of negative typologies when describing parent profiles.

\section{Discussion, Conclusion, and Recommendations}

Due to their important role in their children's education, establishing close cooperation and contact with parents is an important goal of any school. In order for a school to be able to offer quality education, it has an absolute need to cooperate and work with the family on defining, guiding, and increasing both the ability and capacity of the student. According to Gümüşeli (2004), the first and most important condition for creating cooperation between the school and families is that both sides know their role and are ready to work in mutual cooperation to fulfill their roles. From this perspective, the necessary studies must be performed and more effective activities of superior quality developed in order to increase cooperation between schools and families and to support students' education at IHSSs.

Based on how the IHHS school administrators reflected their views, especially in terms of gaining academic success and religious values, having parents with different expectations from these schools is understood to indirectly affect communication between the school's administration, its teachers, and parents. As a matter of fact, according to the participants, these different expectations are the principle reason for the group of problems vocational class teachers experience with students and parents. Through their curriculum and extracurricular activities, IHHSs aim to cultivate proficient and well-equipped students in these two areas. However, academic achievement is, to a large extent, used to measure their success in achieving their aim. One reason for this is because the vocational courses taught in IHSSs are unique and not taught in other high schools and questions related to these courses are not asked on university entrance exams, leading students and parents to adopt an educational understanding that prioritizes academic achievement over the acquisition of religious knowledge and values.

Investigating IHHS school administrators' views on parental participation in the education process, this study has reached the conclusion that subsequent studies on relevant areas should investigate the views of teachers, parents, and even students, as they all play an important role in building, maintaining, and improving cooperation between the school and family. Together with this, the following suggestions can be made to increase parents' participation in the education process based on the data obtained in the research:

- School administrators and teachers should make efforts toward providing parents with an approach to school-family cooperation and should draw attention to 
this subject by informing them that this collaboration is closely related to their children's academic success.

- Parents of students attending IHHSs should be more informed about these schools and their program structure.

- Opportunities that do not require parents to be wealthy should be created by identifying how they can contribute and actively participate in cooperative efforts within their own means.

- In addition to the steps to be taken toward parents, school administrators and teachers, being the other stakeholders in this cooperation, must be open to gaining knowledge about this process and they must not only become proficient in methods to facilitate and ensure family participation in the educational process but also gain the necessary skills to communicate harmoniously with parents. 